\title{
PROTECTIVE EFFECT OF CURCUMA LONGA ADMINISTRATION ON LUNG OF MICE EXPOSED TO CADMIUM
}

\author{
SUMAN SHARMA, AMRITA KUMARI* \\ Department of Zoology and Environmental Sciences, Punjabi University, Patiala, Punjab, India. Email: amritasim16@gmail.com
}

Received: 09 August 2018, Revised and Accepted: 4 September 2018

ABSTRACT

Objective: Cadmium (Cd) is a toxic heavy metal which is introduced into the environment by various anthropogenic and natural activities. It can cause various health problems even at low concentration by inducing oxidative damage in tissues of organisms. Nowadays, the focus has been raised toward the use of herbal treatment against the heavy metal toxicity. Hence, the present study was aimed to investigate the protective effect of curcumin (Cur) against Cd-induced toxicity in the lung of albino mice.

Materials and Methods: Albino mice were divided into 4 groups and 5 mice were kept in each group. The experiment was carried out for 15 and 45 days. Group 1 mice were kept as control. Group 2 mice were given an oral dose of $1 \mathrm{mg} / \mathrm{kg}$ body weight of Cd on alternate days. Group 3 mice were administered an oral dose of $1 \mathrm{mg} / \mathrm{kg}$ body weight of $\mathrm{Cd}$ on alternate days and $100 \mathrm{mg} / \mathrm{kg}$ body weight of Cur daily. Group 4 mice were received an oral dose of $100 \mathrm{mg} / \mathrm{kg}$ body weight of Cur daily. Autopsies were done on 15 and 45 days post-treatment.

Result: Biochemical observations showed an increased level of lipid peroxidation and decreased activity of antioxidant enzymes, i.e., superoxide dismutase, catalase, and glutathione peroxidase. However, Cur administration improved the level of malondialdehyde and oxidative stress in lung tissue by its antioxidant activity. Furthermore, cotreatment of $\mathrm{Cd}$ and Cur ameliorated the antioxidant level.

Conclusion: The results of the present experiment showed the protective action of Cur on the Cd-induced oxidative damage in the lung of mice.

Keywords: Oxidative damage, Antioxidant enzymes, Ameliorate and toxicity.

(C) 2018 The Authors. Published by Innovare Academic Sciences Pvt Ltd. This is an open access article under the CC BY license (http://creativecommons. org/licenses/by/4. 0/) DOI: http://dx.doi.org/10.22159/ajpcr.2018.v11i10.29010

\section{INTRODUCTION}

Heavy metals are natural components of the Earth's crust, and the concentration of several heavy metals has increased in the environment as a result of anthropogenic activities. Environmental contamination due to heavy metals is becoming a global issue because of the toxicological damage posed by such metals to human health [1]. Cadmium (Cd) is one such heavy metal which is causing various health hazards. The agency for toxic substances and disease registry ranks Cd as $7^{\text {th }}$ in the list of top 20 hazardous substances [2] and also it has been classified as "Category I" human carcinogen by International Agency for Research on Cancer [3].

Cd causes the tissue injury by generating oxidative stress and physiological defects [4-7]. Cd leads to the formation of reactive oxygen species (ROS) by affecting mitochondrial electron transport chain. Reactive oxygen species cause the cellular damage when there is an imbalance between ROS and antioxidant defense system, i.e., superoxide dismutase, catalase (CAT), Glutathione peroxidase (GPx), or reduced GSH $[8,9]$

Human exposure to Cd mainly occurs by inhalation or ingestion. Ingesting contaminated food or water is the main source of Cd toxicity [1012]. Cd enters the body through the respiratory tract in people who are occupationally exposed to $\mathrm{Cd}$ and in cigarette smokers [13]. By inhaling $\mathrm{Cd}$, respiratory tract gets injured. However, lung epithelium is an effective barrier for harmful molecules, but Cd can pass through the alveolar cells and can reach the blood [14]. In workers, inhaling fumes of $\mathrm{Cd}$ and contaminated air could cause lung edema, shortness of breath, pneumonitis [15], and acute respiratory distress syndrome [16].

Nowadays, herbal formulations are gaining lots of interest against heavy metal poisoning. Curcumin (Cur), a yellow color compound is obtained from the rhizome of Curcuma longa Linn. (Family Zingiberaceae) [17]. It is a used as a spice and coloring agent in food and cosmetics. Cur has been shown to possess many biological properties, for example, anti-inflammatory, anticarcinogenic, antioxidant, anticoagulant, antimutagenic, antidiabetic, antifungal, antibacterial, antiviral, anticoagulant, antiulcer, hypercholesterolemia, hypotensive, and cardioprotective [18-23]. Antioxidants play a critical role in preventing oxidative stress in the human body [24]. Cur, an antioxidant can remarkably inhibit the generation of ROS both in vitro and in vivo [25]. Hence, the present research work was carried out to investigate the ameliorating efficacy of Cur against Cd-induced toxicity in the lungs of albino mice.

\section{MATERIALS AND METHODS}

\section{Animals}

Albino mice weighing 20-22 g were procured from Central Research Institute, Kasauli. They were acclimatized for 10-15 days and given standard mice feed and ad libitum access to tap water. The animals were handled with proper human care in accordance with the guidelines of the Institutional Animal Ethical Committee.

\section{Chemicals}

Cd chloride $\left(\mathrm{CdCl}_{2}\right)$ and Cur were purchased from HiMedia Laboratories Pvt., Ltd., Mumbai. $\mathrm{CdCl}_{2}$ was dissolved in distilled water and was administered to mice orally. An aqueous suspension of Cur was made [26] and administered orally to mice.

\section{Experimental design}

Mice were divided into the following 4 groups:

Group 1 mice were kept as control.

Group 2 mice were administered an oral dose of $1 \mathrm{mg} / \mathrm{kg}$ body weight of Cd on alternate days for 15 and 45 days. 
Group 3 mice were given an oral dose of $1 \mathrm{mg} / \mathrm{kg}$ body weight of $\mathrm{Cd}$ on alternate days and $100 \mathrm{mg} / \mathrm{kg}$ body weight of Cur daily for 15 and 45 days. Group 4 mice were given an oral dose of $100 \mathrm{mg} / \mathrm{kg}$ body weight of Cur daily for 15 and 45 days.

Autopsies were done on 15 and 45 days post-treatment. All control and treated animals were sacrificed, and the lung was removed, freed of adipose tissue, and blotted dry and were processed for biochemical analysis.

\section{Biochemical studies}

Lung homogenate was prepared with the help of tissue homogenizer in $3 \mathrm{ml}$ of phosphate buffer and used for estimation of lipid peroxidation from tissue extract with the method of Wilbur et al. [27], SOD was assessed by the method of Das et al. [28], CAT by themethod of Aebi [29], and GPx by the method of Rotruck et al. [30]

\section{Statistical analysis}

The data were analyzed using the Student's t-test.

\section{RESULTS AND DISCUSSION}

In the present study, toxic effects of $\mathrm{CdCl}_{2}$ and protective effects of Cur on lungs of albino mice were studied and the results obtained from the study are discussed.

Malondialdehyde (MDA) is the main byproduct of lipid peroxidation, and it can be effectively linked to oxidative injuries in tissues [31]. A significant $(\mathrm{p}<0.0001)$ increase in MDA content in the Cd-treated mice was observed in comparison to control at both 15 and 45 days posttreatment. However, the increase in MDA content was more significant at 45 days. Whereas, the Cur treatment significantly decreased the MDA level in $\mathrm{Cd}+$ Cur-treated mice in comparison to control group and but no significant ( $p>0.05$ ) changes were observed in only Curtreated groups at both the intervals (Fig. 1). This is in accordance with the previous studies in which heavy metals elevated the MDA level in the lung tissue [32]. Lipid peroxidation basically denotes free-radical generation. Oxidative damage of the cell membrane can induce damage to other cellular components through the reaction between metal ions and cell organelles. According to Manca et al. [33], lipid peroxidation is an advanced and sensitive reaction to Cd toxicity. Rana and Verma [34] also reported that increased intake of $\mathrm{Cd}$ results in its retention and peroxidative damage in soft tissues.

Superoxide dismutase (SOD) activity was significantly decreased $(\mathrm{p}<0.0001)$ in the Cd-treated group in comparison to the control group of mice at both the intervals. Cur administration ameliorated the decreased SOD activity in $\mathrm{Cd}+\mathrm{Cur}-$ treated group. Whereas, Cur-treated group showed no significant $(p>0.05)$ changes as compared to control at both intervals (Fig. 2). These results are in agreement with the work of other authors $[35,36]$ who reported that as SOD is a metalloenzyme; reduction and depletion in its activity may be because of dysfunctional conformational change which can be due to the replacement of $\mathrm{Zn}^{2+}$ present in SOD by Cd. Furthermore, Cd replaces other metals mostly manganese is resulting in inhibition of SOD activity [37]. The tissue toxicity at increased ROS production is associated with decreased level of an antioxidant enzyme such as SOD [38,39].

A highly significant $(\mathrm{p}<0.0001)$ decrease in CAT was observed in Cdtreated mice as compared to control at days 15 and 45 . Cd+Cur-treated group showed decreased CAT activity as compared to the Cd-treated group, and Cur alone treated group showed normal CAT activity at both intervals (Fig. 3). Cd causes enzyme inhibition by separating the iron in the catalytic subunit of CAT [40]. Decreased CAT activity may also be due to the high generation of reactive oxygen species that are above the detoxification capacity of antioxidant enzymes resulting in the development of tissue damage [41]. It is in agreement with the results of other authors [42,43]. According to Abu-Taweel [24], Cur enhanced the activity of antioxidant enzymes (SOD, CAT, and GSH) in rats against heavy metal toxicity. Jamakala and Rani [44] explained that CAT activity gets declined because of high accumulation of $\mathrm{H}_{2} \mathrm{O}_{2}$ in the tissues and as a resulting in $\mathrm{Cd}$-induced peroxidation of lipids in $\mathrm{Cd}$-treated mice.

A significant $(\mathrm{p}<0.0001)$ decrease in GPx activity was observed in mice treated with $\mathrm{Cd}$ as compared to control mice at 15 and 45 days posttreatment. Cur significantly increased the gpx activity in $\mathrm{Cd}+$ Cur-treated mice as compared to Cd-treated group (Fig. 4). GPx is also one of the antioxidant enzymes directly affected by $\mathrm{Cd}$ as it replaces the selenium present in the enzyme $[45,46]$. The main function of gpx is the removal

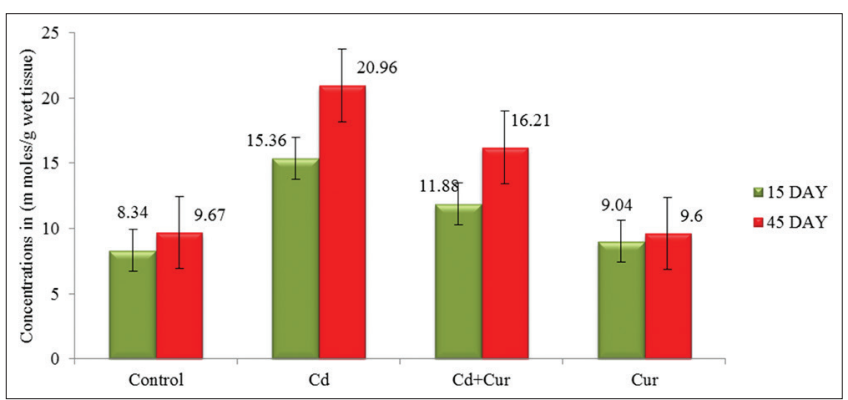

Fig. 1: Malondialdehyde level in control and treated groups at 15 and 45 days treatment

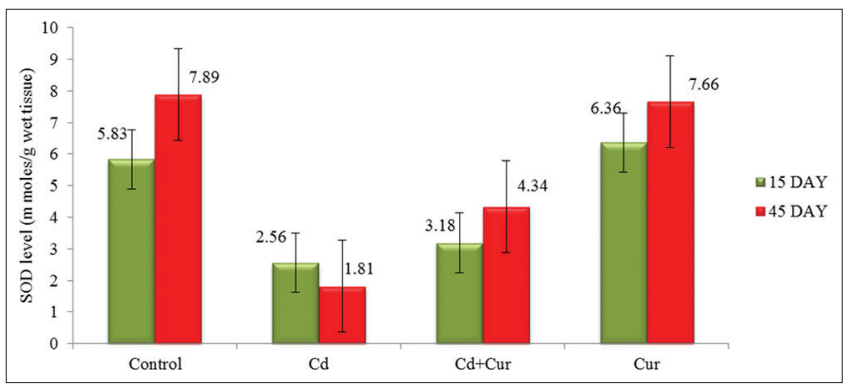

Fig. 2: Superoxide dismutase activity in control and treated groups at 15 and 45 days treatment

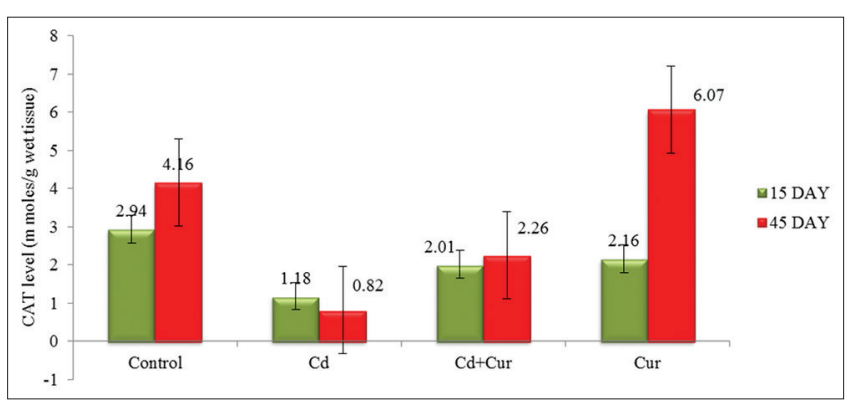

Fig. 3: Catalase activity in control and treated groups at 15 and 45 days

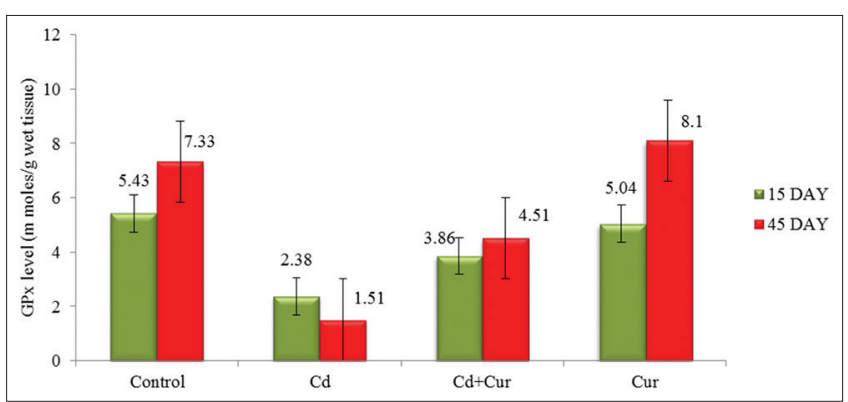

Fig. 4: Glutathione peroxidase activity in control and treated groups at 15 and 45 days 
and detoxification of hydrogen peroxide and lipid hydroperoxides in the presence of oxidized GSH [47]. The decrease in gpx activity could be due to the increased free radicals induced by Cd toxicity.

\section{CONCLUSION}

$\mathrm{CdCl}_{2}$ is one of the hazardous heavy metals. In the present study, Cdinduced the oxidative stress in lungs which resulted in elevated lipid peroxidation and declined activity of antioxidant enzymes (SOD, CAT, and GPx). Whereas, Cur administration ameliorated the Cdinduced changes in MDA, SOD, CAT, and GPx activities. Therefore, it is recommended that daily intake of Cur can overcome the Cd toxicity in organisms.

\section{ACKNOWLEDGMENT}

The authors gratefully acknowledge the facilities provided by the Department of Zoology and Environmental Sciences, Punjabi University, Patiala, Punjab, India, to pursue the research work and also the Institutional Ethical Committee for permitting to work on mice. Furthermore, the financial aid extended by UGC in the form of Rajiv Gandhi National Fellowship for minority students is greatly appreciated.

\section{AUTHORS' CONTRIBUTIONS}

Both the authors have contributed equally.

\section{CONFLICTS OF INTEREST}

The author declares that there are no conflicts of interest regarding the publication of this paper.

\section{REFERENCES}

1. Lopes TM, Barcarolli IF, de Oliveira CB, de Souza MM, Bianchini A. Effect of copper onion content in isolated mantle cells of the marine clam Mesodesma mactroides. Environ Toxicol Chem 2011;30:1582-5.

2. Attia AM, Ibrahim FA, Abdel-Latif NA, Aziz SW. Antioxidant effect of curcumin against cadmium chloride-induced oxidative stress in blood of rats. J Pharm Phytother 2014;6:33-40.

3. Sarkar AG, Ravindran, Krishnamurthy V. A brief review on the effect of cadmium toxicity: From cellular to organ level. Int J Bio Technol Res 2013;3:17-36.

4. Chatterjee S, Kundu S, Sengupta S, Bhattacharyya A. Divergence to apoptosis from ROS induced cell cycle arrest: Effect of cadmium. Mutat Res 2009;663:22-31.

5. Choong G, Liu Y, Xiao W, Templeton DM. Cadmium-induced glutathionylation of actin occurs through a ROS-independent mechanism: Implications for cytoskeletal integrity. Toxicol Appl Pharmacol 2013;272:423-30.

6. Nunes B, Caldeira C, Pereira JL, Gonçalves F, Correia AT. Perturbations in ROS-related processes of the fish Gambusia holbrooki after acute and chronic exposures to the metals copper and cadmium. Environ Sci Pollut Res Int 2015;22:3756-65.

7. Wei X, Qi Y, Zhang X, Gu X, Cai H, Yang J, et al. ROS act as an upstream signal to mediate cadmium-induced mitophagy in mouse brain. Neurotoxicology 2015;46:19-24.

8. Jemai H, Messaoudi I, Chaouch A, Kerkeni A. Protective effect of zinc supplementation on blood antioxidant defense system in rats exposed to cadmium. J Trace Elem Med Biol 2007;21:269-73.

9. Newairy AA, El-Sharaky AS, Badreldeen MM, Eweda SM, Sheweita SA. The hepatoprotective effects of selenium against cadmium toxicity in rats. Toxicology 2007;242:23-30

10. Ohta H, Cherian MG. Gastrointestinal absorption of cadmium and metallothionein. Toxicol Appl Pharmacol 1991;107:63-72.

11. Nordberg GF. Historical perspectives on cadmium toxicology. Toxicol Appl Pharmacol 2009;238:192-200.

12. Andersen O, Nielsen JB, Nordberg GF. Factors affecting the intestinal uptake of cadmium from the diet. In: Nordberg GF, Herber RF, Alessio L, editors. Cadmium and the environment. Lyon: IARC; 1992. P. 173-87.

13. Cadmium and Cadmium Compounds. IARC Monogr Eval Carcinog Risks Hum 1993;58:119-237.

14. Bressler JP, Olivi L, Cheong JH, Kim Y, Bannona D. Divalent metal transporter 1 in lead and cadmium transport. Ann N Y Acad Sci 2004;1012:142-52.
15. Seidal K, Jörgensen N, Elinder CG, Sjögren B, Vahter M. Fatal cadmium-induced pneumonitis. Scand J Work Environ Health 1993;19:429-31.

16. Barbee JY Jr. Prince TS. Acute respiratory distress syndrome in a welder exposed to metal fumes. South Med J 1999;92:510-2.

17. Sinha R, Anderson DE, McDonald SS, Greenwald P. Cancer risk and diet in India. J Postgrad Med 2003;49:222-8.

18. Ammon HP, Wahl MA. Pharmacology of Curcuma longa. Planta Med 1991;57:1-7

19. Chattopadhyay I, Biswas K, Bandopadhyay U, Banerjee R. Turmeric and curcumin: Biological actions and medicinal applications. Curr Sci 2004;87:44-53.

20. Suzuki M, Nakamura T, Iyoki S, Fujiwara A, Watanabe Y, Mohri K, et al. Elucidation of anti-allergic activities of curcumin-related compounds with a special reference to their anti-oxidative activities. Biol Pharm Bull 2005;28:1438-43

21. Kurup VP, Barrios CS, Raju R, Johnson BD, Levy MB, Fink JN, et al. Immune response modulation by curcumin in a latex allergy model. Clin Mol Allergy 2007;5:1

22. Nazam Ansari M, Bhandari U, Pillai KK. Protective role of curcumin in myocardial oxidative damage induced by isoproterenol in rats. Hum Exp Toxicol 2007;26:933-8.

23. Kurup VP, Barrios CS. Immunomodulatory effects of curcumin in allergy. Mol Nutr Food Res 2008;52:1031-9.

24. Abu-Taweel GM. Curcumin attenuates lead $(\mathrm{Pb})$-induced neurobehaviorl and neurobiochemical dysfunction: A review. Int J Pharm Pharm Sci 2018;10:23-8.

25. Biswas SK, McClure D, Jimenez LA, Megson IL, Rahman I. Curcumin induces glutathione biosynthesis and inhibits NF-kappaB activation and interleukin-8 release in alveolar epithelial cells: Mechanism of free radical scavenging activity. Antioxid Redox Signal 2005;7:32-41.

26. Kamel R, Hashim AA, Ali SA. Palliative effect of curcumin On Stzinduced diabetes in rats. Int J Pharm Pharm Sci 2014;6:558-63.

27. Wilbur KM, Bernheim F, Shapiro OW. The thiobarbituric acid reagent as a test for the oxidation of unsaturated fatty acids by various agents. Arch Biochem 1949;24:305-13.

28. Das K, Samantha L, Chinoy GB. A modified spectrophotometric assay for superoxide dismutase using nitrite formation by superoxide radicals. Indian J Biochem Biophys 2000;37:201-4.

29. Aebi HE. In: Bergmeyr HU, editor. Catalase in Methods of Enzymatic Analysis. Weinheim: Verlag Chemie; 1984. p. 273-86

30. Rotruck JT, Pope AL, Ganther HE, Swanson AB, Hafeman DG, Hoekstra WG. Selenium: Biochemical role as a component of glutathione peroxides. Science 1973;179:588-90.

31. Del Rio D, Stewart AJ, Pellegrini N. A review of recent studies on malondialdehyde as toxic molecule and biological marker of oxidative stress. Nutr Metab Cardiovasc Dis 2005; 15:316-28.

32. Karaca S, Eraslan G. The effects of flaxseed oil on cadmium-induced oxidative stress in rats. Biol Trace Elem Res 2013;155:423-30.

33. Manca D, Ricard AC, Trottier B, Chevalier G. Studies on lipid peroxidation in rat tissues following administration of low and moderate doses of cadmium chloride. Toxicology 1991;67:303-23.

34. Rana SV, Verma S. Protective effects of GSH, vitamin E, and selenium on lipid peroxidation in cadmium-fed rats. Biol Trace Elem Res 1996;51:161-8.

35. Kofod P, Bauer R, Danielsen E, Larsen E, Bjerrum MJ 113Cd-NMR investigation of a cadmium-substituted copper, zinc-containing superoxide dismutase from yeast. Eur J Biochem 1991;198:607-11.

36. Casalino E, Calzaretti G, Sblano C, Landriscina C. Molecular inhibitory mechanisms of antioxidant enzymes in rat liver and kidney by cadmium. Toxicology 2002;179:37-50.

37. Cuypers A, Plusquin M, Remans T, Jozefczak M, Keunen E, Gielen $\mathrm{H}$, et al. Cadmium stress: An oxidative challenge. Biometals 2010;23:927-40.

38. Kim CY, Lee MJ, Lee SM, Lee WC, Kim JS. Effect of melatonin on cadmium-induced hepatotoxicity in male sprague-dawley rats. Tohoku J Exp Med 1998;186:205-13.

39. Morales AI, Vicente-Sa'nchez C, Sandoval JM. Protective effect of quercetin on experimental chronic cadmium nephrotoxicity in rats is based on its antioxidant properties. Food Chem Toxicol 2006;44:2092-100.

40. Messaoudi I, El Heni J, Hammouda F, Saïd K, Kerkeni A. Protective effects of selenium, zinc, or their combination on cadmium-induced oxidative stress in rat kidney. Biol Trace Elem Res 2009;130:152-61.

41. De Castro MA, Neto FF, Lima LM, Da Silva FM, De Oliveira RJ, Zanesco A. Production of free radicals and catalase activity during acute exercise training in young men. Biol Sport 2009;26:113-8. 
42. Yalin S, Comelekoglu U, Bagis S, Sahin NO, Ogenler O, Hatungil R, et al. Acute effect of single-dose cadmium treatment on lipid peroxidation and antioxidant enzymes in ovariectomized rats. Ecotoxicol Environ Saf 2006;65:140-4

43. Dallak M. Camal's mik protects against cadmium chloride induced hypocromic microcytic anemia and oxidative stress in red blood cells of white albino rats. Am J Pharmacol Toxicol 2009;4:136-43.

44. Jamakala O, Rani UA. Amelioration effect of zinc and iron supplementation on selected oxidative stress enzymes in liver and kidney of cadmium-treated male albino rat. Toxicol Int 2015;22:1-9.
45. Lazarus M, Orct T, Aladrovic J, Ljubic BB, Jurasovic J, Blanusa M. Effect of selenium pretreatment on antioxidative enzymes and lipid peroxidation in Cd-exposed suckling rats. Biol Trace Elem Res 2011;142:611-22.

46. Ognjanović BI, Marković SD, Pavlović SZ, Zikić RV, Stajn AS, Saicić ZS, et al. Effect of chronic cadmium exposure on antioxidant defense system in some tissues of rats: Protective effect of selenium. Physiol Res 2008;57:403-11.

47. Kanbur M, Eraslan G, Silici S. Antioxidant effect of propolis against exposure to propetamphos in rats. Ecotoxicol Environ Saf 2009;72:909-15. 